\title{
Abstracts of Papers Presented at the 2019 Annual Meeting
}

\author{
SESSION 1: THE LEGACY OF SLAVERY AND DISCRIMINATION
}

\begin{abstract}
Race, Family Background, and Educational Attainment in the Early TwentiethCentury South
\end{abstract}

We investigate the empirical relationship between educational outcomes observed in adulthood and family background and school quality characteristics, with a particular focus on racial differences. The results shed light on determinants of racial differences in educational attainment, during a period in American history for which little is known about these determinants. Using a sample of children in 1910 matched to their responses to the 1940 census as adults, links family background with student outcomes. We supplement these with household wealth and district-level measures of school quality from administrative records. Preliminary estimates suggest that mean differences in childhood household head's wealth alone can account for as much as 26.23 percent of the racial disparity in years of schooling, and family background characteristics all together can account for 45.55 percent of the racial differential.

RichARD BAKER, The College of New Jersey

\section{How the Legacy of Slavery Survives: Labor Market Institutions and Demand for Human Capital}

In spite of the extensive literature on the legacy of slavery, robust evidence for a convincing mechanism have not been established. In this research, I examine the impact of slavery on long-run development and its detailed mechanism which consists of two key components: labor market institutions and demand for human capital. Using countylevel data from the U.S. South and exploiting exogenous variation in agro-climatic conditions, I show that slavery has impeded long-run economic development through the human capital channel. The mechanism depends on labor market institutions and their impact on demand for human capital. I find from the complete count census data that the history of slavery impeded integration of black workers into the competitive labor market. Moreover, border-county analyses show that selective enforcement of laws and regulations was a primary tool for impeding integration. Through estimating the relative return to education for each county, I argue that blacks living in a region with a greater legacy of slavery had fewer incentives to invest in human capital. In addition, I suggest that racial wage discrimination and selective migration played a role in the persistence of the mechanism. 
The Great Migration and Political Change: Racial Realignment in the U.S. North, 1940-1970

Between 1940 and 1970, more than 4 million African Americans moved from the South to the North of the United States. We study how the inflow of blacks - often excluded from the political process in the South, but eligible to vote in the Northaltered the behavior of northern legislators. Faced with a new constituency deeply concerned about the "southern question," did congressmen in the North become increasingly supportive of the Civil Rights legislation? To answer this question, we match commuting zones to Congressional Districts over time, construct a predicted measure of black inflows across northern areas using a shift-share instrument, and examine several political outcomes - including electoral returns, floor speeches, bill sponsorship, voting behavior on Civil Rights legislation, and signature of discharge petitions.

\section{VAsiliki Fouka, Stanford University and Marco Tabellini, Harvard Business School}

\section{SESSION 2: FAMILY PLANNING AND FERTILITY}

\section{Censorship, Family Planning, and the Historical Fertility Transition}

The historical demographic transition is one of the most important events in history. This study provides new evidence highlighting the key role that censorship and the release of family planning information played in this event. We begin by providing evidence linking the sharp decline in fertility in Britain starting in 1877 to the public release of family planning information that resulted from the famous Bradlaugh-Besant trial. We then provide evidence that the trial had nearly simultaneous effects among British-origin populations abroad, particularly in Canada. These findings highlight the importance of information and changing social norms played in the historical demographic transition, as well as the role that cultural and linguistic ties played in transmitting this information around the world.

Brian Beach, College of William and Mary and Walker Hanlon, New York University

Cohort Effects of Restrictive Abortion Legislation: Evidence from Nineteenth Century Law Variation

According to standard models of fertility, lowering the cost of abortion will raise the average socioeconomic status of born children and improve the long-run outcomes of birth cohorts. Empirical results from 1970s abortion legalization in the United States largely confirm this prediction. We generalize the workhorse fertility model and highlight assumptions under which the standard model's predictions can be overturned. In particular, high returns to child labor, along with budget constraints and high discount rates for low-income households, can each overturn the standard prediction. Moreover, by incorporating cohort size effects in predicting long-run outcomes for marginal children, we show that the general equilibrium effects of abortion legalization, which reflect both child selection and cohort size effects, are ambiguous. Abortion restrictions in the 
nineteenth century United States demonstrate these points. Children born under more restrictive abortion access were of higher socioeconomic status. Nevertheless, larger cohorts induced additional mortality, particularly at younger ages.

\section{Elizabeth Ananat, Duke University, Joanna Lahey, Texas A\&M University,} and Marianne WanamaKer, University of Tennessee, Knoxville

\section{The Baby Boom and Educational Attainment}

In the late 1960s, high school and college graduation rates suddenly stagnated, and in some cases declined, after decades of rapid growth. This sudden change in educational attainment remains largely unexplained. We examine whether the baby boom itself, through changes in the distribution of birth order, can explain part of the overall decline in education completion for these cohorts. We find that the baby boom can explain the majority of the decrease in college completion for white men between the 1952 and 1962 birth cohorts, and the end of the baby boom can explain the majority of the increase in college completion over the following decade. It also explains about half of the decline in high school completion for white men between 1952 and 1962, and half of the increase in high school completion over the next decade.

\section{Christopher Handy and Katharine Shester Washington and Lee University}

\section{SESSION: 3: FORCED LABOR AND THE AFRICAN ECONOMY}

\section{Causes and Consequence of Lobbying: Evidence from Petitions and in the Nineteenth Century Cape Colony}

This paper studies the development of local and central state capacity in the nineteenth century British Cape Colony, at the southern tip of Africa. We first compile archival data on local (municipal and divisions) revenues and expenditures on public goods from 1853 to 1880 . We then examine if and how local governments responded to an exogenous, increased demand for infrastructure due to the discovery of mines and subsequent expansion of the railway network in 1873 . We find local governments on national lines and on lines connecting the coast and mines had the fiscal capacity to raise more revenues from taxes. We also find that local governments allocated relatively more funds to public works (roads, bridges, and water infrastructure) than salaries to employees. The evidence suggests that this era had parts of a well-functioning state that had the capacity to provide infrastructure.

Kara Dimitruk and Johan Fourie, Stellenbosch University

\section{The Emergency: British Detention Camps and the Origins of Distrust in Kenya}

This study examines the long-run effects of British detention camps in colonial Kenya on well-being and trust. During the dawn of colonial rule in Kenya, the British Empire was confronted with a violent uprising to which it responded with far-reaching measures, in effect suspecting anyone sharing the ethnicity of the Mau Mau tribes, and 
incarcerating a significant share of the native population. Exploiting geographic and individual characteristics to identify the affected individuals and households, we show that individuals exposed to detention camps have worse development outcomes today. We use rich contemporary survey data to document that affected individuals tend to be less trusting, accumulate less wealth, and are less literate, even though their ethnic kin belong to the ruling class of contemporary Kenya. We are currently geocoding historical census data to control for pre-camp location characteristics and assess well-being in the 1960s and beyond.

Gerda Asmus, University of Heidelberg, Hebrew University of Jerusalem, Richard Bluhm and ToBias Korn, Leibniz University Hanover

\section{Economic Growth in Sub-Saharan Africa 1885-2008}

Estimates of GDP per capita are provided on an annual basis for eight sub-Saharan African economies for the period since 1885. Although the growth spurt experienced in most of SSA since the mid-1990s has had historical precedents, there have also been episodes of negative growth or "shrinking," so that long run progress has been limited. Despite some heterogeneity across countries, this must be seen as a disappointing performance for the region as a whole, given the possibilities of catch-up growth. Avoiding episodes of shrinking needs to be given a higher priority in understanding the transition to sustained economic growth.

STEPHEN BROADBERry, University of Oxford and LEIGH GARDNER, London School of Economics

\section{SESSION: 4: THE EFFECT OF SOCIAL STRUCTURE \\ AND COLONIAL POLICY IN INDIA}

\section{Caste, Reservation Policy and Social Mobility in India}

To improve the social mobility on the face of 3,500 years old caste system, the Indian Government in 1950 introduced an affirmative action, namely, Reservation Policy (RP). Drawing upon an unused data on university graduates spanning over six decades (19592017), the paper measures, first, the rates of social mobility in India since independence; second, to what extent variations in RP has affected these rates. Results, while match the previous estimates, contradict existing notion that caste based endogamy is the source of social rigidity in India. To explore different channels of this rigidity, this paper further analyzes the academic performance as well as the dynamics of career choices for different caste groups over time. Findings suggest that with prolonged exposure to any discipline of study, the lowest caste groups perform as good as the highest caste, however, the lowest caste groups tend to choose their career differently than the highest counterparts, leading to different socio-economic outcomes that hinder the social mobility. 


\section{Did Railways Affect Literacy? Evidence from India}

In this paper, we study the effect of railways on literacy in colonial India. Using a new dataset on both total and gender-specific literacy at the district level between 1881 and 1931, we estimate the effect of railways using a difference-in-differences approach that compares the change in literacy before and after the arrival of railways within the same district. This approach addresses concerns that districts that were coastal, more developed and more urbanized were the first to be connected by rail in India. Comparing these estimates with cross-sectional regression estimates suggests that cross-sectional estimates are biased upwards. In addition, we also estimate an instrumental variables strategy based on distance from a minimum spanning tree that connects major cities that existed prior to the beginning of railroad construction. Our paper contributes to the literature on railways in economic history by studying the effects on human capital, an important outcome that has been understudied in the global and India-specific literatures.

Latika Hartmann, Naval Postgraduate School and JAMES Fenske University of Warwick,

\section{Governments and the Performance of the English East India Company}

We study how British governments affected the performance of the English East India Company. British governments (e.g., monarchs, parliaments, and political parties) set regulatory and foreign policies that sometimes favored the Company and sometimes not. We study a wide range of Company-related outcomes and use exogenous changes in monarchs and elections to identify how governments mattered. Our results show that changes in monarchs, parliaments, and majority parties all significantly influenced Company investment in shipping. We also use daily stock prices to show significant positive and negative abnormal returns in the Company's stock in the days following the death of some monarchs and elections. Lastly, we provide evidence that some ship captains were more or less likely to sail in months when the government changed. Our results contribute to literatures on policy uncertainty, firm-level behavior, and the nature of governance and institutions in the early modern period.

Dan Bogart and Marco Del Angel, University of California, Irvine

\section{SESSION 5: MEASURING INNOVATION AND THE EFFECTS OF TECHNOLOGICAL CHANGE}

\section{Patterns of Innovation during the Industrial Revolution: A Reappraisal Using Composite Indicators of Patent Quality}

In this paper, we construct a new bibliographic indicator of patent quality for English patents granted in the period 1700-1850. The indicator is based on the relative visibility of each patent both in the contemporary legal and engineering literature and in modern authoritative works on the history of science and technology. The indicator permits to operationalize empirically the distinction between micro and macro-inventions which has featured prominently in the recent debates on the origins of the Industrial Revolution 
(Allen 2009; Mokyr 2009). Our findings indicate that macro-inventions did not exhibit any specific time clustering, while micro-inventions are correlated to the economic cycle. In addition, we also find that macro-inventions were not the result of the activities of "outsiders" and they were characterized by a labor-saving bias. These findings are further explored in the context of mechanical engineering, where we find confirmation that professional and experienced machine-makers were responsible for the most important inventions, while machine users usually engaged in minor improvements.

\section{Alessandro Nuvolari, Sant'Anna School of Advanced Studies, Valentina Tartari, Copenhagen Business School, and Matteo Tranchero, University of California, Berkeley}

\section{Automation in the Historical Mirror: The Bureau of Labor Statistics Hand and Machine Labor Study}

Recent advances in artificial intelligence and robotics have generated a robust debate about the future of work. A similar debate occurred in the late nineteenth century when extensive mechanization first transformed manufacturing. We analyze an extraordinary data set from the late nineteenth century, the BLS "Hand and Machine Labor" study. We focus on transitions at the task level that took place from hand to machine production, and on the impact of inanimate power, especially of steam power, on labor productivity. Our analysis reveals several ways in which current task-based models of automation might be modified to take account of historically relevant effects of mechanization.

JeREMy ATACK, Vanderbilt University, RoBert Margo, Boston University, and PAul RHOde, University of Michigan

\section{Household Vintages: Lifecycle Rigidities and the Effects of Electrification}

Electrification is often regarded as a key transformative force. However, the shortterm effects of electrification found by recent studies are modest. I show theoretically and empirically that accounting for household-level heterogeneity in two enduring decisions, fertility and human capital, can help reconcile these facts by mediating one of the most salient benefits of electrification: the use of women's talent for market production. I build an overlapping generations model where human capital and fertility decisions are concentrated early in life, thus moderating the productive and time-saving benefits of electrification for older women, and dampening the short-term effects of electrification. Using individual-level panel data in 1910-1940 in the United States, and a newly digitized dataset of the universe of generating stations in 1911 and 1919, I then present evidence consistent with these mechanisms. I find that the effects of electrification vary significantly by cohort, initial fertility and schooling, and that these effects are stronger for women. 
SESSION 6: MIGRATION AND LABOR MARKETS IN SOUTH AMERICA

\section{Southern (American) Hospitality: Italians in Argentina and the United States} during the Age of Mass Migration

Italians were the largest contributors to the rise in southern European immigration that took place in the United States at the turn of the twentieth century. This rise fueled anti-immigrant sentiments which concluded with the United States abandoning its opendoor policy for European immigrants. I study the selection and economic outcomes of Italians in Argentina and the United States, the two largest destinations for Italians in this period. Prior cross-sectional work shows that Italians had faster assimilation in Argentina, but is inconclusive on whether this was due to differences in selection or in host-country conditions. I construct data following Italians from passenger lists to population censuses, enabling me to compare migrants with similar regional origins and pre-migration characteristics. First- and second-generation Italians had better economic outcomes in Argentina. Observable pre-migration characteristics cannot explain these differences. Path dependence in migration flows can rationalize these differences in an era of open borders.

Santiago Perez, University of California, Davis

\section{Slaves, Migrants, Development, and Public Goods Provision in Brazil, 1872-1923}

Brazil was the largest importer of slaves during the nearly 400 years of the Atlantic slave trade. Despite this, researchers have struggled to identify an economic legacy of the institution. This is mostly due to the lack of disaggregated data able to capture the intensity of slavery across time and space. I propose to measure the incidence of slavery using the presence of communities founded by runaway slaves: the Quilombos. Employing this measure and municipal level data, I illustrate the adverse impact of slavery on a broad range of indicators of development and public goods provision, both while slavery still existed and in the first half of the twentieth century, more than 30 years after its abolition. Additionally, I juxtapose the slave communities to communities created to host newly arrived migrants from Europe while slavery was not yet abolished and show that these, contrary to the Quilombos, were causally associated with better developmental outcomes.

Andrea Papadia, European University Institute

\section{The 1918 Influenza Pandemic in Brazil: Human Capital Formation and Labor Market Consequences}

This project aims to study the short- and long-term repercussions of the 1918 Influenza Pandemic on demographic, human capital, and labor market outcomes in Brazil. The 1918 Pandemic killed between 20 to 50 million people worldwide and is often coined the greatest epidemic of modern history. Using historical records, we construct a database on socio-economic and health outcomes for all districts in São Paulo, Brazil's cultural and financial center. Using in-country geographical variation on the timing of the event and climatic variables merged with detailed district and municipality level 
information on deaths by cause and measures of social and health infrastructure, we find that the "Spanish flu" had significant short term effects on infant mortality, sex ratios at birth, fertility, and marriage patterns. We then find statistical evidence that there are persistent effects on human capital formation, wages, and on the skill premium.

Amanda Guimbeau, Nidhiya Menon, and Aldo Musacchio, Brandeis University

\author{
SESSION 7: GOVERNMENT AND MARKET RESPONSES \\ TO URBAN AND REGIONAL CHANGE
}

\title{
Financing the Rebuilding of the City of London after the Great Fire of 1666
}

The Great Fire of 1666 consumed most of the City of London. Rebuilding the infrastructure and public buildings, including numerus parish churches and St. Paul's Cathedral was taken by the London Corporation, the City's governing body. This required funding on an extraordinary scale. This paper presents archival data and analyzes how, in the absence of banks, a stock market and without central government funding, the City was able to fund this massive rebuilding project. The City borrowed at historically low rates from its citizens and outside investors, partly secured on its' reputation and partly secured by future coal tax receipts. The rebuilding project was completed in less than 10 years. However, having invested in public goods and without additional sources of revenue, it eventually led to the Corporation's default in 1683.

D’maris Cofman and Judy Stephenson, University College London, and Nathan Sussman, Hebrew University of Jerusalem

\section{Local Origins and Implications of the 1930s Urban Debt Crisis}

Rising incomes and automobile ownership encouraged widespread suburbanization and urban growth during the 1920 s, which was facilitated by debt-financed infrastructure spending on the part of cities. When the Great Depression struck, it brought a crisis in which cities were weakly positioned to respond to local economic crisis. We first document the rise of long-term debt issuance by city governments during the 1920s. We then identify the factors that explain the variation in city debt loads in 1929 and find that cities constrained by state-level rules for borrowing were significantly less indebted in 1929. Lastly, we show that cities with high debt loads in 1929 made bigger spending cuts between 1931 and 1933. Together, these results shed light on the urban experience during the 1920s and 1930s and suggest that urban fiscal policy played a substantial role in contributing to the deflationary forces at work during the Great Depression.

James Siodla and Samara Gunter, Colby College

\section{Why Aren't People Leaving “Janesville”?: Industry Persistence, Trade Shocks and Mobility}

We examine what makes cities resilient to competition by combining city-industry employment and labor market outcomes from the late eighteenth century and today. We find that cities which recorded employment in the same industries for the past century 
are slower in adjusting to the China shock. Facing foreign competition, employment responses and out-migration is far less pronounced in these cities than in comparable cities which experienced industrial churning throughout the twentieth century, while unemployment increased. Using value surveys and local labor market flow data, we argue that the existence of the same industries throughout a century, which offered lowskill jobs in these cities, shaped local and industry-specific identities. This increased the cost of out-migration and the local populations willingness to switch sectors in face of external shocks. To account for the potential positive selection of workers in cities offering stable low-skill jobs, we employ a shock to low-skilled industries at the beginning of American industrialization. Local competition from convict labor made lowskilled production unprofitable in some community zones that happened to be close to a prison adopting it. We show that in community zones that lost low-skilled industries at the turn of the twentieth century, workers upgraded their skills and moved out, making those locations resilient to weathering the China shock of the early twenty-first century.

\section{Michael Poyker, Columbia University and Sebastian Ottinger, University of California, Los Angeles}

\section{SESSION 8: THE ROLE OF THE SOCIAL SAFETY NET IN THE UNITED KINGDOM AND UNITED STATES}

\section{Pension Incentives and Labor Force Participation: Evidence from the Introduction of Universal Old-Age Assistance in the United Kingdom}

We estimate the labor force participation (LFP) response to the introduction of means-tested minimum pensions in the United Kingdom through the Old-Age Pension Act (OAP) of 1908. The OAP was a major social policy intervention and the first one to universally target older workers in a time of very limited social protection. The empirical framework is based on three decennial census waves $(1891,1901,1911)$, covering the full U.K. population. We identify the LFP effects of the program based on variation at the age-based eligibility threshold between 69 and 70. Our results show a considerable and abrupt decline of 6.3 to 7.6 percentage points in the LFP rate when older men turn 70. This sudden drop only occurs at the age cutoff and only after the OAP was implemented. The unique historical setting allows us to study the full labor supply effects of an old-age assistance program.

Philipp Jaeger and Matthias Giesecke, RWI Essen

\section{Will You Miss Me When I'm Gone? Family Networks and Social Outcomes, England 1750-2019}

In any society individuals are embedded in family networks: parents, grandparents, uncles, aunts, and cousins. Most social science disciplines - anthropology, economics, and sociology - assume these family networks play an important role in the outcomes for children. It is certainly the case that even controlling for parent characteristics, the characteristics of other relatives often help predict child outcomes. Here we argue, however, using an extensive lineage of English families, 316,000 persons born 1750 2012 , that there is good evidence that the family network played no causal role in child 
outcomes. In this lineage we know which relatives were alive or dead when children are born, which were geographically proximate at birth, and which distant. We find dead and distant relatives were just as strongly predictive of social outcomes as living and proximate ones. Relatives seemingly provide only information about the underlying characteristics of parents. Parents alone determined child social outcomes.

Greg Clark, University of California, Davis and NeIL Cummins, London School of Economics

\section{Who Benefits from Federal Welfare Spending? Evidence from the Introduction of Progressive Cost Sharing}

By the late twentieth century states controlled most aspects of public assistance programs in the United States while the federal government paid most of the costs. We use the 1958 Social Security Act amendments which increased cost-sharing rates for lower-relative to higher-income states, to ask how federal cost sharing affects the structure of welfare programs as well as other state spending and revenue choices. We use a difference-in-differences design that compares changes in state finances before and after 1958 lower-income ("more treated") versus higher-income ("less treated") states. We use newly digitized data on welfare outcomes by state and month from 1936 through 1965 as well as data on state budgets from 1942 to 1965 from Census of Government and Compendium of State Finances. Our results address long-standing public finance questions about crowd-out in a federal system and historical questions about the growth of the safety net and trends in state finances.

Andrew Goodman-Bacon, Vanderbilt University

\section{SESSION 9: GROWTH AND THE EMERGENCE OF INDUSTRIAL CLUSTERS}

\section{The Research University, Science, and the Origins of Industrial Clusters}

We study whether the presence of research universities and technical schools caused the emergence of industry clusters during the Second Industrial Revolution in historical Germany. In the early 1800 s, German states invested heavily in research universities, established science institutes attached to universities, and founded technical schools to train engineers in an effort to catch up to the world technological frontier. Research universities and technical schools generated local human capital advantages attractive to industry. We find that towns being in close proximity to technical schools before 1820 attracted more manufacturing establishments after 1820 . Overall, our result show a causal link between state investments in human capital and industrialization during the Second Industrial Revolution in Germany, highlighting the importance of the state to the country's catch up to the world technological frontier.

Jeremiah DitTmar, London School of Economics and Ralf Meisenzahl, Board of Governors of the Federal Reserve System 


\section{The Innovator Next Door: Intra-City Clustering of Inventors and Entrepreneurs}

While it is well known that innovative activities cluster in particular cities, little is known about the clustering of innovators within cities. I use U.S. decennial census manuscripts to construct measures of residential clustering for innovative individuals. Entrepreneurs are more clustered than other occupational groups. Residential clustering of entrepreneurs is decreasing from 1910 to 1940, while cross-city measures of clustering show either no trend or an increase over the same period. Ongoing work extends these results to patentees, as well as determining whether innovation rates and quality are higher in more diversified vs. specialized areas and for more vs. less connected individuals. Finally, I exploit the movement of innovative individuals to estimate the causal effect of proximity to an innovator on innovative outcomes.

Michael Andrews, National Bureau of Economic Research

\section{Space Race: Automation Innovation and Labor's Share}

Labor's share has declined across a broad range of industries in many economies around the world over the last 50 years. We examine the effects of one of the largest public investments in science of the twentieth century to understand how automation innovation affects the labor share over the long term. The Space Race-launched in response to the Soviet Union's Sputnik satellite in 1957-represents a shock to local automation innovation, which occurred virtually independent of local labor market conditions. Our analysis of city-industry level Manufacturing Census and National Aeronautics and Space Administration (NASA) publications data from 1947 to 2012 reveals two main findings. First, labor share fell five years after local NASA innovation shocks occurred. Over the longer term, as firms and workers adjusted, we find that labor share increased in response to NASA technology shocks. Our analysis sheds new light on the dynamics of the impact of automation technology on workers.

Shawn Kantor, Florida State University and Alex Whalley, University of Calgary

\section{SESSION 10: INSTITUTIONAL CHANGE IN EUROPE}

\section{Identifying the Origins of the Great Divergence in Europe: Rare Events, Outbreaks of the Social Revolts and Divergence in Labor Institutions}

Based on a change point-analysis and other econometric techniques, the paper identifies specifically those critical years that represented breakpoints in the real wage gap between two representative cities, London and Florence, from the late Middle Ages to the beginning of the modern age. Subsequently, an analytical framework is proposed, based on the theories of rare events and endogenous institutional change, to explain how some events in those critical years could have influenced to an institutional divergence in Europe. The waves of the plague, the state of war and some social revolts were fundamental to explain why labor institutions in England moved quickly toward preindustrial labor markets, with more flexible institutional arrangements, in contrast to the other 
regions in Europe where serfdom remained many more years. The paper contributes to identify when the divergence in Europe could have begun, based on a macroeconomic approach and on an empirical analysis

Alfonso Carballo-Perez, Bocconi University

Meritocracy versus the Market: The Cardwell Reforms and Staffing the Officer Corps of the British Army

After 1871, the possibility of purchasing the next rank no longer existed. Various reforms, some already in place and others created after the abolition of purchase, reduced the need for a pecuniary signal like purchase and replaced it with opportunities for officers to demonstrate competence in marksmanship, cavalry drill, and infantry maneuvers. Army Camps at Aldershot and Shorncliffe in England and at Curragh in Ireland, as well as the elimination of the ensigncy and the assignment of training to the regimental captain and his subalterns, provided a new institutional setting for both the monitoring and the evaluation of officers and enlisted men. Moreover, after 1 January 1860 no officer was eligible for appointment to the upper ranks of Army administration until he had matriculated in and passed final examinations at the Staff College. All of these reforms effectively replaced the mechanism of a largely decentralized market for commissions with a meritocratic system of professional judgments in the staffing a modern officer corps.

Esther Redmount, Colorado College, Arthur Snow and Ronald Warren, University of Georgia

\section{Female Partners and Corporate Founders in Imperial Russia, 1894}

The paper documents the characteristics of Russian manufacturing establishments with female partners or founders. Somewhat uniquely for this period, women in the Russian Empire held property independently from their husbands. Women commonly appeared as partners or founders of Russian firms, but their impact on firm organization, production technology, and performance is poorly understood. In a partnership, women could bring capital to manufacturing establishments or serve to shield the firm's assets in the event of bankruptcy. In corporations, female founders could contribute political or economic connections helpful in navigating the incorporation process or securing founding capital. This paper uses newly collected manufacturing census data from 1894 to document cross-industry differences in machinery, labor force composition, and survival present in establishments with female partners or founders. This evidence contributes to larger discussions on the prevalence and roles of female entrepreneurs in historical cases of countries that industrialized relatively late.

Tanya Byker and Amanda GregG, Middlebury College 


\section{SESSION 11: STATE CAPACITY AND ECONOMIC POLICY IN ASIA OVER THE LONG RUN}

\section{State Formation and Bureaucratization: Evidence from Pre-Imperial China}

How does one build a centralized bureaucratic state? Using hand-collected data, I present the first systematic evidence on patterns of wars, state-building and activity of political elites in pre-imperial China, and argue that they do not support the "warmakes-states" theory. Instead, I postulate that war can dampen state-building: when military threat is large, rulers need to incentivize agents to defend against invasion by giving them residual claims to the land. Then, I demonstrate increasing activity of nonnobles in state administrations, and argue that human capital is an important channel for state-building as it reduces the cost of administrative appointments. I develop a model to formalize these claims, and test the model's predictions in light of historical examples and data. I find that bureaucratic rule is more likely to transpire in regions that face less military threat, and when agents have weaker political connections.

Joy CHEN, Stanford University

Meritocracy and Its Discontents: Evidence from Repeated School Admission Reforms

We investigate the impacts of changing school admissions systems in higher education. In doing so, we take advantage of the world's first known implementation of nationally centralized admissions and its subsequent reversals in early twentiethcentury Japan. This centralization was designed to make the school seat allocation more meritocratic, but we find a tradeoff between meritocracy and equal regional access to higher education and career success. Specifically, in the short run, in line with theoretical predictions, the meritocratic centralization led students to apply to more selective schools and make more inter-regional applications. However, as high-ability students were located disproportionately in urban areas, the centralization caused urban applicants to crowd out rural applicants from higher education. Moreover, these impacts were persistent: Four decades later, compared to the decentralized system, the centralized admissions increased the number of urban-born career elites (e.g., high-income earners) relative to rural-born ones.

Chiaki Moriguchi and Mari TanaKa, Hitotsubashi University, and Yusuke Narita, Yale University

\section{SESSION 12: INSTITUTIONS AND CONSEQUENCES OF WESTERN SETTLEMENT}

\section{The Determinants and Impacts of Historical Treaty-Making in Canada}

In the late nineteenth century, the North American bison was brought to the brink of extinction in just over a decade. We show that the bison's slaughter led to a reversal of fortunes for the Native Americans who relied on them. Once the tallest people in 
the world, the generations of bison-reliant people born after the slaughter were among the shortest. Today, formerly bison-reliant societies have between 20-40 percent less income per capita than the average Native American nation. We argue that federal Indian policy that limited out-migration from reservations and restricted employment opportunities to crop based agriculture hampered the ability of bison-reliant societies to adjust in the long run, generating lasting regional disparities associated with other indicators of social dislocation, such as suicide and unrest.

MAGGie Jones, University of Victoria, Donna FeIR, Federal Reserve Bank of Minneapolis, and Rов Gillezeau, University of Victoria

\section{Land Inequality and Human Capital: Evidence for the United States from the Homestead Act}

This paper uses historical records of land patents and county level census data to estimate the impact of the Homestead Act of 1862 - an egalitarian land distribution policy implemented in the United States - on land inequality, school enrollment, and literacy during the late nineteenth and early twentieth centuries. The results show that the Homestead Act reduced land inequality and increased school enrollment and literacy, and that there were no heterogeneous effects on school enrollment by sex, but the effect is driven by the impact on children of primary school age. Using the Homestead Act as an instrument for land inequality, an DID-IV estimation procedure shows that the latter had a strong negative impact on school enrollment. This result adds evidence to the literature that links inequality with poor access to education, and makes a methodological contribution in that identification does not rely on variation across geographic, climatic, or soil characteristics, but instead it relies on variation in the implementation of a public policy. I also show that results are robust to the inclusion of state specific year fixed effects and are not driven by convergence, and in fact I argue that convergence in school enrollment was a consequence of the Homestead Act.

\section{Nicolas Lillo Bustos, Pontificia Universidad Javeriana}

\section{Short- and Long-Term Environmental Consequences of Farmland Conservation Programs: Historical Evidence from the Great Plains, 1930-1980}

The 1930's American Dust Bowl compelled the federal government to undertake the largest peacetime budgetary expansion in American history. A significant fraction of this policy bundle was related to farmland conservation policies and was especially designed to restore the soil conserving grassland in the Great Plains. I evaluate these post-Dust Bowl farmland conservation programs to understand the persistent and immediate impacts of incentive-dependent land conservation policies, especially on the existence of grassland areas and soil erosion level. Using historical data on cropland and grassland from the Great Plains counties and exploiting spatial and temporal variation of the policy, I find positive and persistent effects of the early land conservation policies on the future size of the grassland area. Also, soil erosion level in the pasture land is reduced in the long run. The immediate annual effects of soil conservation budget 
shows the importance of federal subsidy in farmer's decision making. The spatial heterogeneity in the effect depends on agricultural land tenancy, access to irrigation, access to credit, number of the farms and size of the farms.

Aparna Howlader, University of Illinois, Urbana-Champaign

\section{SESSION 13: THE EVOLUTION OF BANKS AND FINANCIAL MARKETS}

\section{The Credit Boom in Loans to Brokers and Stock Prices Fluctuations in the 1920s}

This paper investigates how the credit boom in brokers' loans interacted with fluctuations in stock prices and macroeconomic variables during the 1920s. I will analyze financial data from all Federal Reserve districts including regional stock exchanges operating at that time. I will estimate demand, supply, monetary and financial shocks in a Bayesian VAR using sign restrictions identification methods. The results should indicate how effective monetary policy contraction was to stabilize credit growth and stock prices, and uncover the expected drop in output and price level. Besides, I will be able to measure how financial factors contributed to output fluctuations, and how credit supply shocks affected the level of stock prices.

FabrizIo Marodin, University of California, Irvine

\section{International Banks: Reagents of the First Globalization}

The first wave of globalization from 1850-1914 fundamentally transformed the nature of international economic relationships. How did a key financial innovation "long-distance international banking" matter for this process? We examine how the expansion of this financial technology shaped international trade in the first wave of globalization. We find that international banks were associated with the direction of trade. The presence of an international bank is associated with a significant rise in trade between the home country and destination. International banks likely facilitated the flows of information that were necessary for international trade.

\section{Christopher Meissner, University of California, Davis, WILFRIED KISLING, University of Oxford, and CHENZI Xu, Harvard University}

A New Chronology of U.S. Asset Price Bubbles, 1825-1929

Asset price bubbles have played an important role in the two most severe downturns in U.S. economic history of the past century: the Great Contraction of 1929-1933 and the Great Recession of 2007-2009. However, little is known about whether these episodes are typical. We develop a new chronology of U.S. asset price bubbles between 1825-1929, using a narrative approach. We read all relevant articles from more than a century's worth of leading financial and business newspapers and identify bubbles based on contemporaneous descriptions. We use our new chronology to investigate the relationship between bubbles and the macroeconomy. Are bubbles more likely to 
form in certain macroeconomic environments? Does the typical bubble "pop" or merely fizzle out? Are popping bubbles associated with banking panics? What types of bubbles pose greater danger of spilling over onto the broader economy? Finally, we investigate what lessons modern policymakers can take from connections between credit conditions and nineteenth-century asset price bubbles.

Matthew Botsch, Bowdoin College and ANDREw JALIL, Occidental College

SESSION 14: POLITICAL ECONOMY OF THE INTERWAR PERIOD

\section{Financial Destruction: Confiscatory Taxation of Jewish Property and Income in Nazi Germany}

Nazism got into power in Germany in 1933 with the explicit goal of destroying the economic livelihood of Germany's Jewish population. This short paper is about identifying the main fiscal instruments used in this process, and about assessing the quantitative impact. Seminal work of Junz (2002) has made use of the data, enhanced by detailed archival evidence from Austrian archives. I update and revise these estimates. My principal quantitative finding of this paper is that in relative terms, the fiscal booty from the dispossession of Germany's Jews was small: over a range of estimates, the Jewish share of Germany's real wealth was not far out of line with the (small) Jewish population share. The principal qualitative result is that the spoils from Jewish dispossession were nowhere nearly large enough to warrant an economic interpretation of the Holocaust as in Aly (2007).

Albrecht Ritschl, London School of Economics

\section{The Refugee's Dilemma: Evidence from Jewish Outmigration in Nazi Germany}

By the end of 1938, more than two-thirds of the Jewish community was still located in Germany. In this paper we estimate the push and pull factors involved in the outmigration of Jews facing persecution in Nazi Germany from 1933 to 1942. We build a structural model of migration under uncertainty on the life threat and then we perform counterfactual policy experiments in order to quantify how migration restrictions in destination countries affected the fate of Jews. Our analysis particularly highlights the role of social learning and information spillovers by assessing how migration outflows within social networks provided a signal of the severity of the threat to the peers. The empirical investigation makes use of a unique dataset that records the migration history of almost the entire universe of Jews living in Germany over the period.

Johannes Buggle, University of Lausanne,

Thierry MAYer, Sciences Po, and

Seyhun Orcan Sakaldi, University of Lausanne, and Mathias Thoenig University of Lausanne 


\section{A Positive Effect of Political Dynasties: The Case of France's 1940 Enabling Act}

The literature on political dynasties in democracies treats them as a homogenous group and emphasizes their negative effects. By contrast, we argue that dynasties differ according to their origin and that democratic dynasties - dynasties whose founder was a defender of democratic ideals - support democracy more than others. This conclusion is based on the analysis of the vote by the French parliament on 10 July 1940 granting full power to Marshall Philippe Patain, thereby ending the Third French Republic and aligning France with Nazi Germany. Using individual votes and newly-collected data from the biographies of the members of parliament, we observe that members of a democratic dynasty had a 7.6 to 9.0 percentage points higher probability to oppose the act than members of other political dynasties or representatives belonging to no political dynasty. Suggestive evidence points to pro-democracy environments as the main driver of this effect.

Kim Oosterlinck, Jean Lacroix, and Pierre-Guillaume Meon, Université Libre de Bruxelles

\section{SESSION 15: THE TECHNOLOGY AND POLITICAL ECONOMY OF CULTURAL CHANGE}

\section{Is the "Great Man" Theory of History Dead? How Luther's Personal Ties Affected the Diffusion of the Early Reformation}

Was censorship effective in sixteenth century European society? We present a new database of the population of books censored by the Catholic Church during the CounterReformation period (sixteenth and beginning of seventeenth centuries) containing information on titles, authors, topics (religion, sciences, social sciences and arts), languages, georeferenced printing places and printers. We describe patterns of censorship across political entities in Europe over time, using the index produced in Rome (starting in 1564) as well as local indexes of prohibited books such as the Index of Louvain and the Index of the Spanish Inquisition. We then test the effects of censorship on the number of printed books, on the location of thinkers, on the spread of Protestantism and ultimately on city growth. Preliminary results suggest that Catholic censorship did have an impact on the publication of books, on the diffusion of knowledge and on economic growth.

SASCHA BeCKer, University of Warwick, Steven Pfaff, University of Washington, and JARED RuBIN, Chapman University

\section{Entrepreneurship and Communal Tax Liability: The Political Economy of Early Modern Jewish-Polish Symbiosis}

During the early modern period Poland became the demographic center of world Jewry. Jews were invited by the Polish kings and the nobility to occupy certain economic niches within the Second Serfdom economy. Over time they developed a long- 
term symbiotic relationship with their hosts while receiving unprecedented liberties and political autonomy. The epitome of this demographic, economic, and political golden age was the Council of the Four Lands (1580-1764; Heb.: va'ad arba' aratzot), an autonomous national representative body whose main role was the administration of the self-taxation of the entire Jewish population of Poland. Why was Poland so hospitable to Jews, and why were Jews preferred over other available groups for their designated economic roles? I argue that part of the explanation relies on the fact that relative to agriculture and manufacturing, income generated from entrepreneurial pursuits is harder to observe by the ruler, and therefore harder to tax directly. In the institutional and political context of early modern Poland, the most efficient method to tax such economic activity was through group-taxation and mutual liability at the widest possible scope. Jews stood out because their communal institutions enabled such wide-scope internal taxation at minimal political risk. Thus, I explain the Jewish-Polish symbiosis as a result of the surplus that was generated due to the ability to impose a group-tax at the regional and the national levels on an entire ethnic community that specialized, and often fully dominated, the entrepreneurial sectors of the economy.

\section{Yannay Spitzer, Hebrew University of Jerusalem}

\section{Mass Media and Cultural Homogenization: Evidence from the Golden Age of Radio in the United States, 1920-1940}

Do mass media build cultural homogenization? If so, do they borrow from different sub-cultures equally or do they facilitate the assimilation to the cultural center of the country? I study the effects of the rise of radio broadcasting on cultural homogenization and mass society in the United States from the early 1920s to the eve of WWII. I construct a new dataset containing technical specification of all the transmitting towers in the country for every two years of the interwar period. With the help of a new signal prediction algorithm, I use tower specifications to impute radio coverage across the country. To measure cultural assimilation, I resort to the 1930 and 1940 full count census and use name patterns for all the cohorts of newborns in my study period. I construct indexes of name similarity between receiving locations and the most common names at the national level. I test whether radio broadcasting played an important role in building the idea of national culture and shared identity. I do so by exploring whether exposure to radio programs affected family decision concerning the name patterns of their offspring. Further, I examine the differential effect of radio content from large networks located in the cultural center of the country.

GianluCa Russo, Boston University

\section{SESSION 16: INFRASTRUCTURE AND LAND ASSEMBLY}

\section{Ghosted Towns: Commodities and Transportation in Economic Development}

In the case of nineteenth century U.S. frontier settlement, a town had truly "arrived" when a post office was established there. Post offices are subject to annual reporting that permits us to observe when a given town lost its post office. By identifying towns that have been abandoned, or as we call it, ghosted, we can compare these to commodities 
prices and transportation network choices. Proponents of infrastructure investment often cite economic development benefits, benefits that we believe are overestimated due to the displacement that typically lurks within such estimates. In sum, our underlying intuition is simple: What can we learn from the pattern of ghosted towns across the U.S. West? Using post office records to determine the year that a post office left a given town, we provide a more robust understanding of how transportation network route choices result in distributional consequences that can ultimately ghost entire towns.

ERIC Alston, University of Colorado, Boulder and Bryan Leonard, Arizona State University

\section{Playing Checkers in Chinatown}

In 1905-1935 the city of Los Angeles bought the water and land rights of the Owens Valley farmers and built and aqueduct to transfer the water to the city. The dark story is that the city bullied and isolated reluctant farmers to get cheap water. A map of the farmers plots sold in any given point in time, however, would look like a checkerboard either because the city is intentionally targeting specific farmers, or because the farmers were heterogeneous. We analyze the bargaining between the city and the farmers and the effects that farmers' actions had on one another, and use that evidence to assess the checkerboarding claim. We estimate a dynamic structural model of the farmers' decision on selling to the city. We found that there are large externalities when farmers sold. The externalities were larger for neighboring farmers, and when the selling farmer was closer to the river.

José-Antonio Espin-SÁnchez, Yale University and Santiago Truffa, Tulane University

\section{Freeway Revolts!}

Freeway revolts were widespread protests that erupted across the United States following early urban Interstate construction in the mid-1950s. We present theory and evidence from a variety of sources - including panel data on neighborhoods in U.S. cities, 1950-2010 and changes in travel behavior since the 1950 - to show that reduced quality of life from freeway disamenities inspired the revolts, affected the allocation of freeways within cities, and changed city structure. First, actual freeway construction increasingly diverged from initial plans in the wake of the growing freeway revolts and subsequent policy responses, especially in central neighborhoods. Second, freeways caused slower growth in population, income, jobs, and land values in central areas, but faster growth in outlying areas. These patterns suggest that in central areas, freeway disamenity effects exceeded small access benefits. Third, in a quantitative general equilibrium spatial model, the aggregate welfare benefits from burying or capping highways are large and concentrated downtown, consistent with opposition to urban freeways in central neighborhoods. Disamenities from freeways, versus their commuting benefits, likely played a significant role in the decentralization of U.S. cities. 


\section{Rosenwald Schools and the Intergenerational Mobility of Blacks and Whites: Evidence from North Carolina}

In the early twentieth century, over 5,000 schools were built in the rural South as part of the Rosenwald initiative, a school construction program aimed at improving educational opportunities for black children. Previous work has shown that Rosenwald schools had a positive effect on the educational attainment of blacks. In this paper, we will study the impact of Rosenwald schools on long-run labor market outcomes of blacks and whites, including measures of intergenerational mobility. We will explore this question in the context of North Carolina, the state with the largest number of Rosenwald schools, using a new large-scale longitudinal dataset of reconstructed families. Ultimately, we hope to shed new light on the determinants of racial gaps in the early twentieth century.

Shariq Mohammed and Paul Mohnen, University of Michigan

Intergenerational Mobility in American History: Accounting for Race and Measurement Error

Intergenerational mobility is thought to have been higher 100 years ago. However, most historical estimates include few black families and thus discount their low upward mobility. Moreover, historical estimates may poorly measure the father's permanent economic status and therefore suffer from attenuation bias. Using early twentieth century linked census data, I show that persistence of economic status from father to son is over twice as strong when addressing these issues. Using consistent methods over time suggests that intergenerational mobility, based on imputed income, has not declined since the late nineteenth century.

ZACHARY WARD, Baylor University

\section{The Effect of Land Allotment on Native American Households during the Assimilation Era}

Between 1906 and 1924, the U.S. government broke up millions of acres of communally-owned reservation lands under the authority of the Dawes and Burke Acts, and allotted them to individual Native American households. We study the effects of this policy on the affected households, exploiting quasi-random variation in land allotments, and the legal title granted to them. We interact these treatments with household characteristics as well as with ethnographic measures of ancestral tribal norms related to private property and female bargaining power in the household, and with measures of the scale of tribes' subsistence activities. For outcomes, we link the land allotment data to the universe of Native Americans in the 1930 and 1940 U.S. Census and study the effects of allotment on their wealth, occupation and income, and intermarriage with non-natives. 
SESSION 18: INSTITUTIONAL CHANGE:

GENERAL RULES, BANKING AND ANTITRUST

\section{Adopting and Enforcing General Laws in the United States, 1830 to 1880}

One of the key stages in the process of modern economic development is the creation and enforcement of impersonal rules: rules that treat everyone (or everyone within broad categories) the same. Even for the countries like Britain and the United States, we know very little about how this legal and institutional transformation occurred. This paper examines the adoption of "general" laws in the American states between 1830 and 1880. The first general laws concerned organizations, like churches and corporations. In the 1850s states began requiring legislatures to create general laws for a wide spectrum of purposes and often "whenever possible." The paper uses legislative records to establish whether the demise of private and special legislation occurred before or after the constitutional mandates. The paper then examines the legal procedures by which the mandates were enforced to determine whether general law provision were actually constraints on state legislatures.

NaOmi Lamoreaux, Yale University and JoHn Wallis, University of Maryland, College Park

\section{Andrew Jackson's Bank War and the Panic of 1837}

The role of Andrew Jackson's Bank War in the Panic of 1837 has long been the source of politically charged debate. We analyze the collapse of the network of commercial banks chosen to replace the Second Bank derided as Jackson's pets in the Panic. These banks were closely tied to the Democratic Party, were lent tens of millions of dollars in public money, and were granted a privileged position within the banking system. This produced a moral hazard problem, and the pet bank managers responded by taking on excessive levels of risk. Our analysis of bank-level data reveals that the pet banks saw their net liabilities fall and their banknote discounts rise much more than other commercial banks during and after Panic. Counterfactual estimates suggest that the contraction among the pet banks accounted for around 30 percent of the overall contraction in bank liabilities in 1837.

ERIC HiLt, Wellesley College and Katharine Liang, Northwestern University

\section{Circumventing Antitrust Law: Cooperation between Government and Industry during Times of Crisis, 1910-1945}

History has revealed that anticompetitive behavior is more complex that just firm interaction; government has been known to enforce leniently in return for cooperation from firms. Little research investigates anticompetition and cooperative behavior between government and firms. We seek to fill these gaps, focusing on 1910-1945, a period filled with economic and geopolitical volatility. First, we use game theoretic methodology to examine strategic behavior during two states: economic crises and peace. Then, we simulate the theoretical models, estimating parameter regions 
that ensure efficient outcomes. To understand whether those parameters likely existed during periods of collaboration, we compare the parameter outcomes to data on antitrust cases, firm anticompetitive behavior, government enforcement, and measurements of industry and government payoffs. We show that outcomes observed during WWI and the Great Depression can be explained by this model. The simulation shows it is possible to have parameters that result in government leniency, firms cooperating with lenient government, and firms cheating a collaborative system to the detriment of the government and the consumer.

Jenny Rae Hawkins, Case Western Reserve University and Tyler Powell, Board of Governors of the Federal Reserve System 